
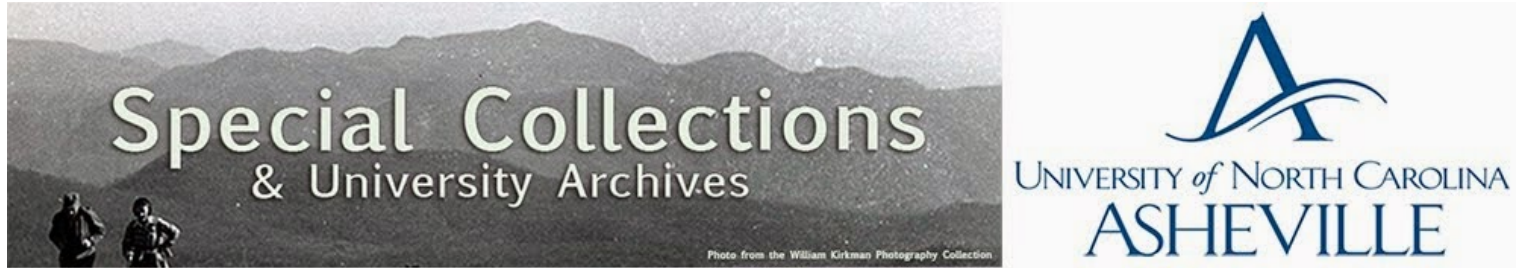

Archived article from the University of North Carolina at Asheville's Journal of Undergraduate Research, retrieved from UNC Asheville's NC DOCKS Institutional Repository: http://libres.uncg.edu/ir/unca/ 
University of North Carolina at Asheville

Journal of Undergraduate Research

Asheville, North Carolina

December 2013

\title{
Physiological Response of Southern Appalachian High-Elevation Rock Outcrop Herbs to Reduced Cloud Immersion
}

\author{
Katherine Culatta \\ Biology \\ The University of North Carolina at Asheville \\ One University Heights \\ Asheville, North Carolina 28804 USA \\ Faculty Advisor: Dr. Jonathan Horton
}

\begin{abstract}
Cloud immersion experienced by high-elevation rock outcrop plants reduces the leaf-to-air vapor pressure deficit (VPD), decreasing transpirational water loss. Frequent cloud immersion might ameliorate water stress in shallowsoil outcrop communities, increasing water use efficiency and growth. Current climate pattern predictions propose that Southern Appalachian cloud immersion frequency will decrease, potentially increasing water stress in rock outcrop plant populations. In this experiment, outcrop specialists Hydatica petiolaris (cliff saxifrage) and Solidago simulans (granite dome goldenrod) were grown in microcosms simulating current, reduced, and absent cloud immersion. Light saturation point and water use efficiency (WUE) increased, and transpiration decreased with decreasing immersion treatment duration. Root mass, root to shoot ratio, and specific leaf mass were greatest in the reduced immersion treatment. Simulated non-immersed conditions resulted in higher VPD, photosynthetic rate, transpiration, and lower WUE across treatments. Results indicate phenotypic plasticity in response to immersion duration for some physiological parameters, suggesting the ability of these plants to acclimate to changing climatic conditions.
\end{abstract}

\section{Introduction}

High elevation rock outcrops are unique habitats characterized by shallow soil patches dominated by herbaceous perennials; they are dispersed widely throughout the southern Appalachian Mountains ${ }^{1,2}$. High elevation rock outcrops provide habitat for rare or endemic plant populations or communities, some of which are disjunct and reproductively isolated from more northern populations ${ }^{2,3}$. Soil water retention is limited on rock outcrops, so moisture availability is likely to limit plant growth. Cloud immersion (fog) might ameliorate water stress in outcrop plants by decreasing leaf-to-air vapor pressure deficit (VPD; the difference in water vapor concentration inside and outside the leaf), resulting in less water loss through transpiration ${ }^{4,5}$. Frequent cloud immersion during the growing season has been recently documented in high elevation areas in southwestern North Carolina. Mount Mitchell (2030 $\mathrm{m}$, Yancey County, NC) experienced at least two hours of cloud immersion on $61 \%$ of days, May-September $2010^{5}$, and immersion frequency increased with elevation in the Black Mountains of southwestern North Carolina, with 1.5 times more immersion at $1960 \mathrm{~m}$ than $1510 \mathrm{~m}$ above sea level ${ }^{6}$. A rock outcrop at 1710 meters above sea level near Blue Ridge Parkway milepost 361 (Buncombe County, NC) experienced at least one hour of cloud immersion on $66.7 \%$ of days and during $29 \%$ of all daylight hours June-September $2012^{7}$.

The effect of current changes in climate patterns on cloud immersion frequency is difficult to predict. Chernykh et al. reported a decrease in global mean cloud base height between 1964 and $1998^{8}$, while Foster reported a trend of increased base height of adiabatically formed cloudbanks in Costa Rican cloud forests ${ }^{9}$. Region-scale studies such as Richardson et al., which documented a rising cloud base height between the 1970s and 2000s along the Appalachian Mountains ${ }^{10}$, provide the most dependable indication of local climate shifts, because global trends 
might not be applicable to all regions. Increasing cloud base height would mean decreased cloud immersion on high-elevation rock outcrops as clouds gradually rise above the elevation of the mountains. Rock outcrop endemics and disjunct populations that are adapted to the cool, moist conditions provided by cloud immersion could be negatively impacted decreased immersion, especially if they are dependent on foggy conditions for water conservation. Shifts in temperature also have the potential to negatively affect rock outcrop flora. Earth's mean annual temperature rose $0.6{ }^{\circ} \mathrm{C}$ from 1902-2002, with regional variation in climate patterns ${ }^{11}$. In eastern North America, the effect of increased temperature has been seen through progressively earlier spring plant phenological events, changes in bird migration, and shifts in plant and insect ranges northward or to increased elevation ${ }^{11,12}$. The two primary ways species can respond to environmental changes are through migration to more suitable (i.e. cooler) latitudes or altitudes or through phenotypic acclimation to the new conditions ${ }^{13}$. Because of the high elevation and specific habitat requirements of rock outcrop endemics, populations are unlikely to shift their ranges and would have to respond to changes in temperature, precipitation, and cloud immersion through genetic selection or phenotypic plasticity. Rare or endemic plant species tend to have low genetic variation, which decreases their potential to adapt to shifting moisture and temperature patterns ${ }^{3,13,14}$.

Reinhardt et al. found that cloud immersion increases diffuse light penetration into the understory of spruce-fir forests, but decreases direct light availability for plants in open areas ${ }^{15}$. For plants in an exposed rock outcrop environment, the two major effects of cloud immersion are a decrease in available light and a decrease in VPD. Cloud immersion has the potential to increase the carbon gained per unit water lost, or water-use-efficiency (WUE), by increasing vapor pressure in the air ${ }^{4,5}$. For rock outcrop plants, this increased WUE might facilitate plant growth, but cloud immersion also has the potential to inhibit growth by decreasing light availability for photosynthesis. The photosynthetic response to cloud immersion depends partially on a plant's light saturation point (Lsat), the intensity at which increased light does not cause a perceptible increase in the rate of $\mathrm{CO}_{2}$ assimilation. Johnson and Smith found that cloud immersion reduced photosynthetic rate in catawba rhododendron (Rhododendron catawbiense), but not in Fraser fir (Abies fraseri), due to a higher light saturation point in $R$. catawbiense ${ }^{16}$. A low light saturation point enables plants to operate at maximum photosynthetic rates during the reduced light conditions of cloud immersion and might be an adaptation to an environment with frequent fog. Even for plants with high Lsat, the trade-off of decreased photosynthetic rate in favor of increased water conservation might be metabolically beneficial during water stress. Stomatal conductance $\left(g_{s}\right)$ is the main control point of $\mathrm{CO}_{2}$ diffusion into and $\mathrm{H}_{2} \mathrm{O}$ diffusion out of the leaf ${ }^{17}$. Stomata respond to light, as well as other environmental factors. The sensitivity of stomata to decreased photosynthetic photon flux density (PPFD) can vary evolutionarily or by growth conditions. Knapp and Smith found that stomata of the riparian herb Senecio tranigularis (arrowleaf ragwort) grown under low water stress were insensitive to changes in PPFD $^{18}$. Decreased light caused a decrease in photosynthetic rate but transpiration remained constant, decreasing WUE. In contrast, stomata of Helianthella quinquenervis (fivenerve helianthella), grown in a meadow under water stress, closed rapidly in response to decreased PPFD; this decreased both photosynthetic and transpiration rates such that WUE remained constant.

The current study assessed the responses of two high-elevation rock outcrop specialist species to reduced cloud immersion. Solidago simulans Fernald, granite dome goldenrod, is a narrowly endemic goldenrod of Appalachian North Carolina, South Carolina, and Georgia, occurring in thin soil mats on granite domes ${ }^{19}$. Hydatica petiolaris Rafinesque, cliff saxifrage (syn. Saxifraga michauxii, Michaux's saxifrage) is endemic to the Southern Appalachian Mountains, occurring in moist to dry rock outcrops, periglacial boulderfields, or rocky seeps ${ }^{19}$. These species were chosen because they occur in different habitat types and belong to different families, representing diversity within rock outcrop specialist flora. If physiological responses in these species are plastic, plants grown in more water stressed (lower immersion frequency) conditions would be expected to have a stronger stomatal response to changes in light and VPD, maintaining higher water use efficiency. Plants under water stress would also be expected have a higher root to shoot ratio to maximize water intake ${ }^{20}$ and a greater specific leaf mass due to smaller cells with slow expansion and thick cell walls ${ }^{21}$. Plants exposed to frequent cloud immersion would be expected to develop lower light compensation and light saturation points in response to decreased light availability.

\section{Methods}

\subsection{Experimental Methods}

Hydatica petiolaris and Solidago simulans seeds were collected from plants on rock outcrops (near Blue Ridge Parkway Milepost 361, at $35.724^{\circ} \mathrm{N}, 82.352^{\circ} \mathrm{W}$, and from Whiteside Mountain, Jackson County, NC, $35.081^{\circ} \mathrm{N}$, 
$83.138^{\circ} \mathrm{W}$, respectively) in Fall 2012. Seeds were cold stratified for 16 weeks at $4{ }^{\circ} \mathrm{C}$, then germinated in a controlled environment plant growth chamber (E-8, Conviron, Winnipeg, Manitoba, Canada) at $14^{\circ} \mathrm{C}$ with a $16-\mathrm{h}$ photoperiod for eight weeks. Seedlings were then transferred to $0.5 \mathrm{~L}$ pots layered with coarse gravel below $4 \mathrm{~cm}$ of potting soil. Soil depth was based on observations of outcrop plants studied in Summer 2012, where soil depth ranged from 1.3 to $22.1 \mathrm{~cm}$, with a mean of $5.4 \mathrm{~cm}^{7}$. Transplanted seedlings remained in the growth chamber for 12 additional days, during which time temperature was increased by $1{ }^{\circ} \mathrm{C}$ every other day to $20^{\circ} \mathrm{C}$. This eased the plants' transitions into a greenhouse, whose afternoon ambient temperature was approximately $24^{\circ} \mathrm{C}$.

Three microcosms were constructed in the greenhouse at the University of North Carolina at Asheville by assembling $113 \times 57 \times 64 \mathrm{~cm}$ PVC frames, then wrapping the frame in heavy clear plastic to contain fog and allow light penetration from ambient light and from two $400 \mathrm{~W}$ metal halide lamps positioned above the microcosms. Light level above the plastic microcosm sheeting averaged $230 \mu \mathrm{mol} \mathrm{m}^{-2} \mathrm{~s}^{-1}$, and light levels at non-immersed plants averaged $90 \mu \mathrm{mol} \mathrm{m} \mathrm{m}^{-2} \mathrm{~s}^{-1}$. Shallow rectangular $8 \mathrm{~L}$ plastic containers were filled with tap water for fog treatment and placed at one end of each microcosm. To disperse fog, $18 \mathrm{~cm}$ diameter clip fans were positioned at the end of each microcosm such that airflow was directed at the surface of each fogger container but did not cause perceptible wind in the rest of the microcosm. Cloud immersion treatments were established based on outcrop monitoring during summer 2012 that found $29 \%, 53 \%$, and $18 \%$ of all daylight hours were cloud immersed, cloudy, and clear, respectively ${ }^{7}$. Based on this, immersion durations of 6 hours (somewhat more than average field conditions), 3 hours (50\% of 6-hour treatment), and 0 hours (control) were established. Treatment type (6-hour, 3-hour, or 0-hour immersion) was randomly assigned to each microcosm, and ultrasonic mist makers (DK5-24X, Nanhai Technsin Electronic Co., Guangdong, China) were placed in the 6-hour and 3-hour fogger containers. During the nine-week treatment period, automatic timers controlled the foggers, fans and lamps such that the 6-hour treatment received fog from 0630 to 1230 daily, the 3-hour treatment received fog from 0630 to 0930 daily, and all plants experienced 14 hours of light each day, 0600 to 2000 . The 30 healthiest-looking transplanted seedlings of each species were removed from the growth chamber and randomly divided among three microcosms, so that each microcosm contained ten individuals of each species. Positioning within the microcosm was randomized, with individuals of each species alternating in a checkerboard pattern. Fans were kept on in all three treatments for the duration of cloud immersion in the 6-hour treatment (0630-1230). All plants were watered with approximately $50 \mathrm{~mL}$ tap water every other day and were fertilized with 18-18-21 NPK Miracle-Gro ${ }^{\mathrm{TM}}$ at the beginning of microcosm treatment and at 4 weeks (about halfway through the experiment). Temperature and humidity were monitored in each microcosm using dataloggers (iButton, Maxim Integrated, San Jose, CA, U.S.). Photographs of plant leaves were taken at a 7day interval, and total plant leaf area was calculated using digital imaging software (Image-J, National Institutes of Health, Washington, DC).

Plant responses to light levels were quantified using an automated light curve program on the Li-6400 portable photosynthesis system (LI-COR Biosciences, Lincoln, NE, U.S.). Five plants of each species from each microcosm treatment were selected randomly for analysis. Light curves were performed by exposing each plant to a sequence of $1000,900,700,500,400,300,200,100,90,70,50,10$ and $0 \mu \mathrm{mol} \mathrm{m}^{-2} \mathrm{~s}^{-1}$ PPFD and measuring photosynthetic rate at each light quantity. Photosynthetic analysis software (Photosyn Assistant, Dundee Scientific, Dundee, Scotland, U.K.) was used to fit a curve of photosynthetic rate vs. light level to determine the dark respiration $\left(\mathrm{R}_{\mathrm{d}}\right)$, maximum photosynthetic rate $\left(\mathrm{P}_{\mathrm{nmax}}\right)$, quantum yield $(\phi)$ light compensation point $(\mathrm{LCP})$, and light saturation point (Lsat) for each plant. Photosynthetic rate -internal $\mathrm{CO}_{2}$ concentration $\left(\mathrm{P}_{\mathrm{n}}-\mathrm{C}_{\mathrm{i}}\right)$ curves were performed by exposing each plant to a sequence of $700,400,300,200,100,50,700,700,1000,1500$, and 2000 ppm atmospheric $\mathrm{CO}_{2}$ concentration, measuring photosynthetic rate at each quantity, and constructing a fitted curve of $\mathrm{P}_{\mathrm{n}}$ vs. $\mathrm{C}_{\mathrm{i}}$ for each plant. External $\mathrm{CO}_{2}$ concentrations were chosen in order to determine photosynthetic response to $\mathrm{CO}_{2}$ from very low $(50 \mathrm{ppm})$ to very high $(2000 \mathrm{ppm})$ concentrations. Two measurements at $700 \mathrm{ppm}$ were implemented after the $50 \mathrm{ppm}$ measurement to allow recovery from the low photosynthetic rate at $50 \mathrm{ppm}$ before further increasing $\mathrm{CO}_{2}$ concentration. The $\mathrm{P}_{\mathrm{n}}-\mathrm{C}_{\mathrm{i}}$ curves were used to calculate the photosynthetic rate corresponding to atmospheric $\left(\mathrm{C}_{\mathrm{a}}\right)$ and internal $\left(\mathrm{C}_{\mathrm{i}}\right) \mathrm{CO}_{2}$ concentrations from the four and eight week survey measurements. Stomatal limitation $(l)$ was calculated following Farquhar and Sharkey ${ }^{22}$,

$$
l=\frac{A_{o}-A}{A_{o}}=1-\frac{A}{A_{o}}
$$

Where $\mathrm{A}$ is the observed photosynthetic rate and $\mathrm{A}_{\mathrm{o}}$ is the photosynthetic rate that would occur if there were no resistance to $\mathrm{CO}_{2}$ diffusion, which is the photosynthetic rate on the $\mathrm{P}_{\mathrm{n}}-\mathrm{C}_{\mathrm{i}}$ curve corresponding to ambient $\mathrm{CO}_{2}$ 
concentration. All curves were generated at ambient temperature $\left(26^{\circ} \mathrm{C}\right)$ and relative humidity $(45 \%)$, light curves were generated at ambient atmospheric $\mathrm{CO}_{2}$ concentration $(400 \mathrm{ppm})$, and $\mathrm{CO}_{2}$ curves were performed at saturating light $\left(1000 \mu \mathrm{mol} \mathrm{m} \mathrm{m}^{-2} \mathrm{~s}^{-1}\right)$. Light and $\mathrm{P}_{\mathrm{n}}-\mathrm{C}_{\mathrm{i}}$ curves were generated over three continuous days during week 8 of treatment.

Leaf gas exchange measurements were taken at 4 and at 8 weeks of treatment using the Li-6400. Steady-state gas exchange rates were measured with atmospheric $\mathrm{CO}_{2}$ concentration set to ambient conditions (460 ppm), and other chamber conditions set to simulate average 'clear' field conditions (temperature $=25^{\circ} \mathrm{C}$, photosynthetically active radiation $(\mathrm{PAR})=500 \mu \mathrm{mol} \mathrm{m} \mathrm{m}^{-2}$, relative humidity $(\mathrm{rH})=20 \%$ ). Gas exchange rates were measured again (approximately 2 hours after first measurement) under 'immersed' chamber conditions (temperature $=22^{\circ} \mathrm{C}, \mathrm{PAR}=$ $200 \mu \mathrm{mol} \mathrm{m} \mathrm{m}^{-2} \mathrm{~s}^{-1}, \mathrm{rH}=60 \%$ ). Actual relative humidity during cloud immersion, both in the microcosm and in the field ${ }^{7}$ was around $90 \%$, but we were unable to maintain such high humidity in the chamber during gas exchange measurements, so the maximum attainable $\mathrm{rH}$ of $60 \%$ was implemented instead. Instantaneous WUE was derived by dividing net photosynthesis $\left(\mathrm{P}_{\mathrm{n}}\right)$ by evapotranspiration $\left(\mathrm{E}_{\mathrm{t}}\right)$, yielding the ratio of $\mathrm{CO}_{2}$ gained to water lost.

All plants were harvested after 9 weeks of treatment. Leaf, stem, and root tissue were separated, and final leaf area was measured using a leaf area meter (Li-3000C, LI-COR Biosciences, Lincoln, NE, U.S.). Roots were rinsed to remove excess soil. Tissues were dried at $60{ }^{\circ} \mathrm{C}$ for 48 hours, and dry mass of each tissue was recorded. Root to shoot ratio was calculated by dividing root mass by stem + leaf mass. Specific leaf mass was calculated by dividing leaf mass by leaf area $\left(\mathrm{mg} / \mathrm{cm}^{2}\right)$.

\subsection{Statistical Analysis}

A linear regression of leaf area calculated from week 9 photographs against leaf area measured on harvested leaves resulted in $\mathrm{r}^{2}=0.980$ and $\mathrm{p}<0.0001$, indicating that weekly calculated area is a good predictor of actual leaf area and is valid to use in relative growth rate analysis. Leaf relative growth rate (lrgr) was calculated using the equation

$$
\frac{(\ln (a 2)-\ln (a 1))}{(t 2-t 1)}
$$

where $a 1$ and $a 2$ are the area measured at time one $(t 1)$ and time two $(t 2)$. SAS 9.2 (SAS Institute, Cary, NC, U.S. $)^{23}$ was used to perform a repeated measures ANOVA for weekly leaf area, testing for the within-subjects effect of time, and the interaction of time with species, treatment and species * treatment.

We used ANOVA (SAS Proc GLM) to compare harvest data (stem, leaf, and root mass, root:shoot ratio, specific leaf mass) between species and among treatments, survey measurements $\left(\mathrm{P}_{\mathrm{n}}, \mathrm{g}\right.$, stomatal limitation, $\left.\mathrm{E}_{\mathrm{t}}, \mathrm{VPD}, \mathrm{WUE}\right)$ by species, treatment, and setting (clear or immersed), as well as for interactions among species, treatment and setting. We also used ANOVA (SAS Proc GLM) to compare light curve data $\left(\mathrm{R}_{\mathrm{d}}, \phi, \mathrm{P}_{\mathrm{n} \text { max }}\right.$, LCP, Lsat) by species and treatment.

\section{Results}

\subsection{Microcosm Conditions}

Four of the $30 \mathrm{H}$. petiolaris plants died in the first two weeks of treatment, likely due to transplant shock. Two individuals died in the 3-hour treatment and one died in each the 6-hour and control treatments. An additional $H$. petiolaris plant from the 3-hour treatment was accidentally uprooted following 4-week physiological survey measurements. All $30 \mathrm{~S}$. simulans plants survived the duration of treatment. During immersion treatment (08:00), temperature was comparable in the 3-hour and 6-hour treatments, both of which were lower than the control, while afternoon temperatures were comparable in all three treatments (Table 1). Mean $\mathrm{rH}$ was greater during immersion treatment, and treatments that received immersion maintained higher $\mathrm{rH}$ into the afternoon (Table 1). 
Table 1. Mean temperature and humidity by treatment and week.

\begin{tabular}{llllll}
\hline $\begin{array}{l}\text { Treatment } \\
\text { Week }\end{array}$ & Treatment & $\begin{array}{l}\text { Mean } \\
\text { Temperature } \\
\mathbf{0 8 0 0}\left({ }^{\circ} \mathbf{C}\right)\end{array}$ & $\begin{array}{l}\text { Mean rH }(\%) \\
\mathbf{0 8 0 0}\end{array}$ & $\begin{array}{l}\text { Mean } \\
\text { Temperature } \\
\mathbf{1 6 0 0}\left({ }^{\circ} \mathbf{C}\right)\end{array}$ & $\begin{array}{l}\text { Mean rH }(\%) \\
\mathbf{1 6 0 0}\end{array}$ \\
\hline 4 & & $25.26 \pm 0.30$ & $51.37 \pm 1.36$ & $31.93 \pm 0.86$ & $33.66 \pm 1.92$ \\
& 0 hour & $20.39 \pm 0.45$ & $84.20 \pm 1.98$ & $30.08 \pm 0.88$ & $41.11 \pm 2.46$ \\
& 3 hour & $20.58 \pm 0.21$ & $91.09 \pm 2.68$ & $28.78 \pm 0.40$ & $42.14 \pm 2.46$ \\
8 & 6 hour & $23.48 \pm 0.31$ & $73.21 \pm 1.08$ & $29.21 \pm 0.68$ & $51.24 \pm 1.58$ \\
& 0 hour & $20.08 \pm 0.42$ & $92.79 \pm 1.21$ & $28.59 \pm 0.73$ & $69.58 \pm 1.99$ \\
& 3 hour & $20.19 \pm 0.42$ & $104.74 \pm 2.58$ & $27.97 \pm 0.59$ & $70.42 \pm 1.98$ \\
\hline
\end{tabular}

\subsection{Light Response}

Light curve parameters differed between species, among treatments, and by species*treatment interactions (Table 2; Table 3). Dark respiration rate, quantum yield, LCP and Lsat were higher in S. simulans than $H$. petiolaris across all treatments and chamber conditions. Light saturation point decreased for both species with increasing duration of cloud immersion. Dark respiration rate showed different patterns between species with the highest for $\mathrm{H}$. petiolaris in the three hour treatment, followed by control and then six hour groups, while the highest for $S$. simulans was in the six hour treatment and the lowest in the three hour treatment. Light compensation point decreased with increasing immersion duration for $\mathrm{H}$. petiolaris, but was highest in six hour and lowest in three hour treatments for S. simulans.

Table 2. Mean \pm standard error for light curve parameters: dark respiration $\left(\mathrm{R}_{\mathrm{d}}\right)$, quantum yield $(\phi)$, light compensation point $(\mathrm{LCP})$, and light saturation point $\left(\mathrm{L}_{\mathrm{sat}}\right)$, by treatment and species.

\begin{tabular}{lllll}
\hline Treatment/Species & Mean $\mathbf{R}_{\mathbf{d}}$ & Mean $\mathbf{\phi}$ & Mean LCP & Mean Lsat \\
\hline 0 hour $H$. petiolaris & $-0.6918 \pm 0.1011$ & $0.0461 \pm 0.0042$ & $16.09 \pm 2.10$ & $214.4 \pm 16.7$ \\
0 hour $S$. simulans & $-1.026 \pm 0.0712$ & $0.0558 \pm 0.0022$ & $18.52 \pm 1.50$ & $269.8 \pm 33.8$ \\
3 hour $H$. petiolaris & $-0.8552 \pm 0.0621$ & $0.0470 \pm 0.0022$ & $18.36 \pm 1.45$ & $163.4 \pm 7.3$ \\
3 hour $S$. simulans & $-0.8968 \pm 0.1437$ & $0.0565 \pm 0.0030$ & $15.63 \pm 2.35$ & $221.4 \pm 23.0$ \\
6 hour H. petiolaris & $-0.5862 \pm 0.0249$ & $0.0510 \pm 0.0018$ & $11.61 \pm 0.81$ & $142.3 \pm 12.8$ \\
6 hour $S$. simulans & $-1.422 \pm 0.1153$ & $0.0529 \pm 0.0017$ & $27.32 \pm 3.07$ & $227.4 \pm 13.8$ \\
\hline
\end{tabular}

Table 3. Results of ANOVA for light curve parameters. Significant results shown in bold. For treatment Lsat, 0hour was greater than 6-hour, and 3 hour did not differ from either.

\begin{tabular}{lllll}
\hline Parameter & Factor & df & F value & Pr $>$ F \\
\hline $\mathrm{R}_{\mathrm{d}}$ & Treatment & 2 & 1.13 & 0.3404 \\
& Species & $\mathbf{1}$ & $\mathbf{2 1 . 8 5}$ & $<\mathbf{0 . 0 0 0 1}$ \\
& Treatment * Species & $\mathbf{2}$ & $\mathbf{7 . 2 1}$ & $\mathbf{0 . 0 0 3 5}$ \\
& Treatment & 2 & 0.06 & 0.9449 \\
& Species & $\mathbf{1}$ & $\mathbf{8 . 5 9}$ & $\mathbf{0 . 0 0 7 3}$ \\
& Treatment * Species & 2 & 1.12 & 0.3425 \\
$\mathrm{LCP}$ & Treatment & 2 & 0.60 & 0.5564 \\
& Species & $\mathbf{1}$ & $\mathbf{6 . 5 6}$ & $\mathbf{0 . 0 1 7 1}$ \\
& Treatment $*$ Species & $\mathbf{2}$ & $\mathbf{7 . 5 0}$ & $\mathbf{0 . 0 0 2 9}$ \\
Lsat & Treatment & $\mathbf{2}$ & $\mathbf{3 . 9 2}$ & $\mathbf{0 . 0 3 3 7}$ \\
& Species & $\mathbf{1}$ & $\mathbf{1 3 . 3 2}$ & $\mathbf{0 . 0 0 1 3}$ \\
& Treatment * Species & 2 & 0.28 & 0.7605 \\
\hline
\end{tabular}




\subsection{Survey Measurements}

In the four-week sampling period, immersed chamber conditions resulted in lower VPD, $P_{n}, E_{t}$, and higher $C_{i}$ and WUE across species and treatments (Table 4). Across species and conditions, $\mathrm{P}_{\mathrm{n}}$ was highest in the 3-hour treatment and lowest in the 6-hour treatment, stomatal conductance was lowest in the control treatment, $\mathrm{C}_{\mathrm{i}}$ and $\mathrm{E}_{\mathrm{t}}$ increased with immersion duration, and VPD and WUE decreased with increased immersion (Figs. 1-4). Photosynthetic rate and WUE were higher in $S$. simulans, while $\mathrm{g}_{\mathrm{s}}$ and $\mathrm{C}_{\mathrm{i}}$ were higher in $H$. petiolaris. The two species differed in the response of $\mathrm{P}_{\mathrm{n}}$ and $\mathrm{C}_{\mathrm{i}}$ to chamber setting. Clear conditions resulted in greater $\mathrm{P}_{\mathrm{n}}$ and reduced $\mathrm{C}_{\mathrm{i}}$ in $S$. simulans, while H. petiolaris rates for both parameters were similar for the two settings. The species also differed in the response of $\mathrm{P}_{\mathrm{n}}, \mathrm{g}_{\mathrm{s}}$, and $\mathrm{E}_{\mathrm{t}}$ across treatments. Photosynthetic rate was steady across treatments in H. petiolaris, but highest in the 3-hour treatment in $S$. simulans. For $H$. petiolaris, $\mathrm{g}$ and $\mathrm{E}_{\mathrm{t}}$ increased with duration of cloud immersion, but were greatest in the 3-hour treatment for $S$. simulans. Results of the eight-week sampling period followed the above pattern with some exceptions (Table 4; Figs. 1-3). There were no significant differences for $\mathrm{g}_{\mathrm{s}}$, and treatment did not affect $\mathrm{P}_{\mathrm{n}}, \mathrm{E}_{\mathrm{t}}$, or VPD. Species $\mathrm{E}_{\mathrm{t}}$ response did not vary by treatment, and H. petiolaris $\mathrm{P}_{\mathrm{n}}$ decreased with increasing immersion duration. In $H$. petiolaris, $\mathrm{C}_{\mathrm{i}}$ was higher for the immersed chamber setting, and $\mathrm{C}_{\mathrm{i}}$ increased with treatment immersion duration for the clear setting. Stomatal limitation did not vary significantly by species, treatment, or chamber condition for either week.

Table 4. Results from ANOVA for physiological parameters: photosynthetic rate $\left(\mathrm{P}_{\mathrm{n}}\right)$, stomatal conductance ( $\mathrm{g}$ ), internal $\mathrm{CO}_{2}$ concentration $\left(\mathrm{C}_{\mathrm{i}}\right)$, evapotranspiraiton $\left(\mathrm{E}_{\mathrm{t}}\right)$, vapor pressure deficit $(\mathrm{VPD})$, and water use efficiency (WUE). Significant results are shown in bold. Setting*Species*Treatment interaction was significant for any parameter.

\begin{tabular}{|c|c|c|c|c|c|}
\hline Parameter & Week & Factor & df & F value & Pr $>$ F \\
\hline \multirow[t]{12}{*}{$\mathrm{P}_{\mathrm{n}}$} & 4 & Setting & 1 & 32.04 & $<0.0001$ \\
\hline & & Treatment & 2 & 7.51 & 0.0009 \\
\hline & & Species & 1 & 52.53 & $<0.0001$ \\
\hline & & Setting * Species & 1 & 33.92 & $<0.0001$ \\
\hline & & Treatment $*$ Species & 2 & 3.96 & 0.0223 \\
\hline & & Setting $*$ Treatment & 2 & 0.19 & 0.8242 \\
\hline & 8 & Setting & 1 & 11.42 & 0.0010 \\
\hline & & Treatment & 2 & 1.07 & 0.3475 \\
\hline & & Species & 1 & 1.07 & $<0.0001$ \\
\hline & & Setting * Species & 1 & 3.58 & 0.0615 \\
\hline & & Treatment $*$ Species & 2 & 3.90 & 0.0235 \\
\hline & & Setting * Treatment & 2 & 0.72 & 0.4898 \\
\hline \multirow[t]{12}{*}{$\mathrm{g}_{\mathrm{s}}$} & 4 & Setting & 1 & 0.02 & 0.8840 \\
\hline & & Treatment & 2 & 13.07 & $<0.0001$ \\
\hline & & Species & 1 & 5.73 & 0.0186 \\
\hline & & Setting * Species & 1 & 2.78 & 0.0986 \\
\hline & & Treatment $*$ Species & 2 & 3.42 & 0.0366 \\
\hline & & Setting * Treatment & 2 & 0.59 & 0.5545 \\
\hline & 8 & Setting & 1 & 0.00 & 0.9599 \\
\hline & & Treatment & 2 & 1.67 & 0.1942 \\
\hline & & Species & 1 & 0.09 & 0.7671 \\
\hline & & Setting * Species & 1 & 0.03 & 0.8554 \\
\hline & & Treatment $*$ Species & 2 & 0.37 & 0.6923 \\
\hline & & Setting * Treatment & 2 & 2.57 & 0.0817 \\
\hline \multirow[t]{6}{*}{$\overline{C_{i}}$} & 4 & Setting & 1 & 10.12 & 0.0020 \\
\hline & & Treatment & 2 & 10.77 & $<0.0001$ \\
\hline & & Species & 1 & 36.18 & $<0.0001$ \\
\hline & & Setting * Species & 1 & 6.18 & 0.0146 \\
\hline & & Treatment $*$ Species & 2 & 0.47 & 0.6247 \\
\hline & & Setting * Treatment & 2 & 0.28 & 0.7570 \\
\hline
\end{tabular}




\begin{tabular}{|c|c|c|c|c|c|}
\hline & 8 & Setting & 1 & 18.91 & $<0.0001$ \\
\hline & & Treatment & 2 & 5.88 & 0.0039 \\
\hline & & Species & 1 & 25.52 & $<0.0001$ \\
\hline & & Setting * Species & 1 & 4.08 & 0.0460 \\
\hline & & Treatment $*$ Species & 2 & 0.86 & 0.4254 \\
\hline & & Setting * Treatment & 2 & 3.08 & 0.0503 \\
\hline$E_{t}$ & 4 & Setting & 1 & 147.03 & $<0.0001$ \\
\hline & & Treatment & 2 & 10.47 & $<0.0001$ \\
\hline & & Species & 1 & 1.68 & 0.1985 \\
\hline & & Setting * Species & 1 & 0.89 & 0.3481 \\
\hline & & Treatment $*$ Species & 2 & 3.96 & 0.0223 \\
\hline & & Setting $*$ Treatment & 2 & 1.97 & 0.1444 \\
\hline & 8 & Setting & 1 & 97.31 & $<0.0001$ \\
\hline & & Treatment & 2 & 2.40 & 0.0958 \\
\hline & & Species & 1 & 0.07 & 0.7931 \\
\hline & & Setting $*$ Species & 1 & 0.01 & 0.94914 \\
\hline & & Treatment $*$ Species & 2 & 1.72 & 0.1837 \\
\hline & & Setting $*$ Treatment & 2 & 2.57 & 0.0814 \\
\hline VPD & 4 & Setting & 1 & 1115.06 & $<0.0001$ \\
\hline & & Treatment & 2 & 3.19 & 0.0456 \\
\hline & & Species & 1 & 1.29 & 0.2585 \\
\hline & & Setting * Species & 1 & 0.33 & 0.5682 \\
\hline & & Treatment $*$ Species & 2 & 0.70 & 0.4966 \\
\hline & & Setting $*$ Treatment & 2 & 0.80 & 0.4543 \\
\hline & 8 & Setting & 1 & 2856.03 & $<0.0001$ \\
\hline & & Treatment & 2 & 3.19 & 0.7967 \\
\hline & & Species & 1 & 1.29 & 0.9605 \\
\hline & & Setting $*$ Species & 1 & 0.33 & 0.1841 \\
\hline & & Treatment $*$ Species & 2 & 0.70 & 0.9367 \\
\hline & & Setting $*$ Treatment & 2 & 0.80 & 0.5105 \\
\hline WUE & 4 & Setting & 1 & 25.59 & $<0.0001$ \\
\hline & & Treatment & 2 & 11.84 & $<0.0001$ \\
\hline & & Species & 1 & 31.35 & $<0.0001$ \\
\hline & & Setting $*$ Species & 1 & 0.84 & 0.3612 \\
\hline & & Treatment * Species & 2 & 1.23 & 0.2981 \\
\hline & & Setting $*$ Treatment & 2 & 1.60 & 0.2076 \\
\hline & 8 & Setting & $\mathbf{1}$ & 35.29 & $<0.0001$ \\
\hline & & Treatment & 2 & 4.18 & 0.0181 \\
\hline & & Species & 1 & 22.65 & $<0.0001$ \\
\hline & & Setting * Species & 1 & 0.16 & 0.6935 \\
\hline & & Treatment $*$ Species & 2 & 0.33 & 0.7168 \\
\hline & & Setting $*$ Treatment & 2 & 1.54 & 0.2200 \\
\hline
\end{tabular}




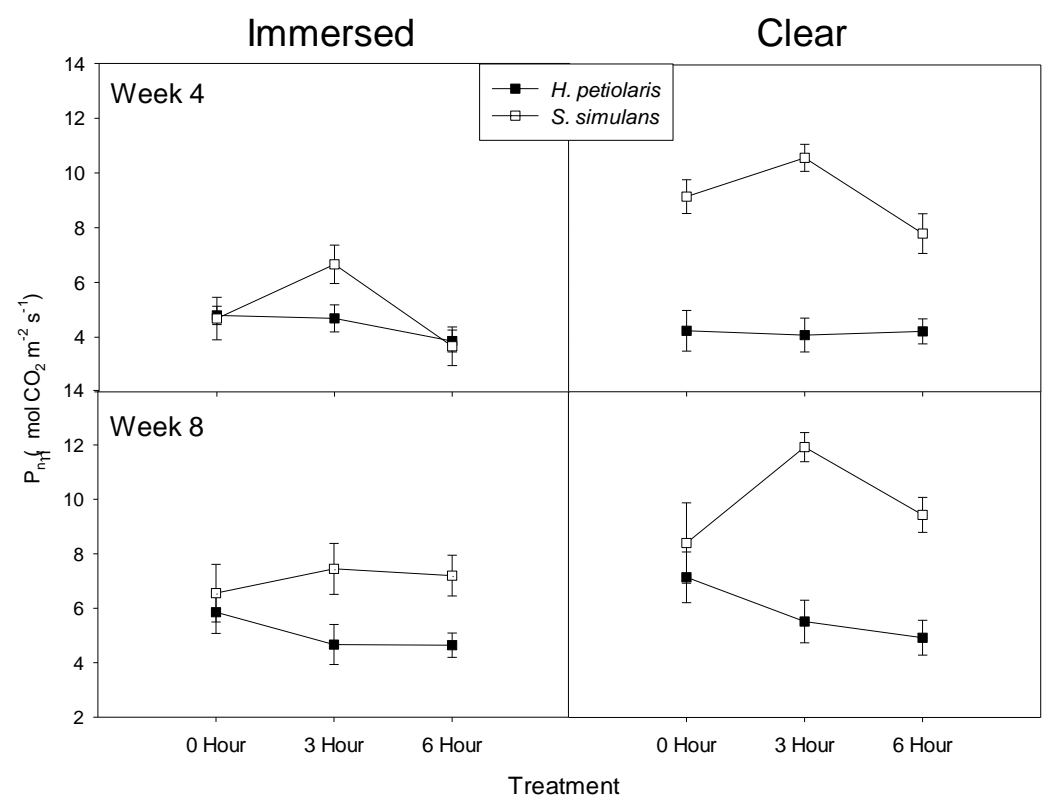

Figure 1. Mean \pm standard error photosynthetic rate $\left(\mathrm{P}_{\mathrm{n}}\right)$ for Hydatica petiolaris and Solidago simulans by treatment, chamber condition, and week.

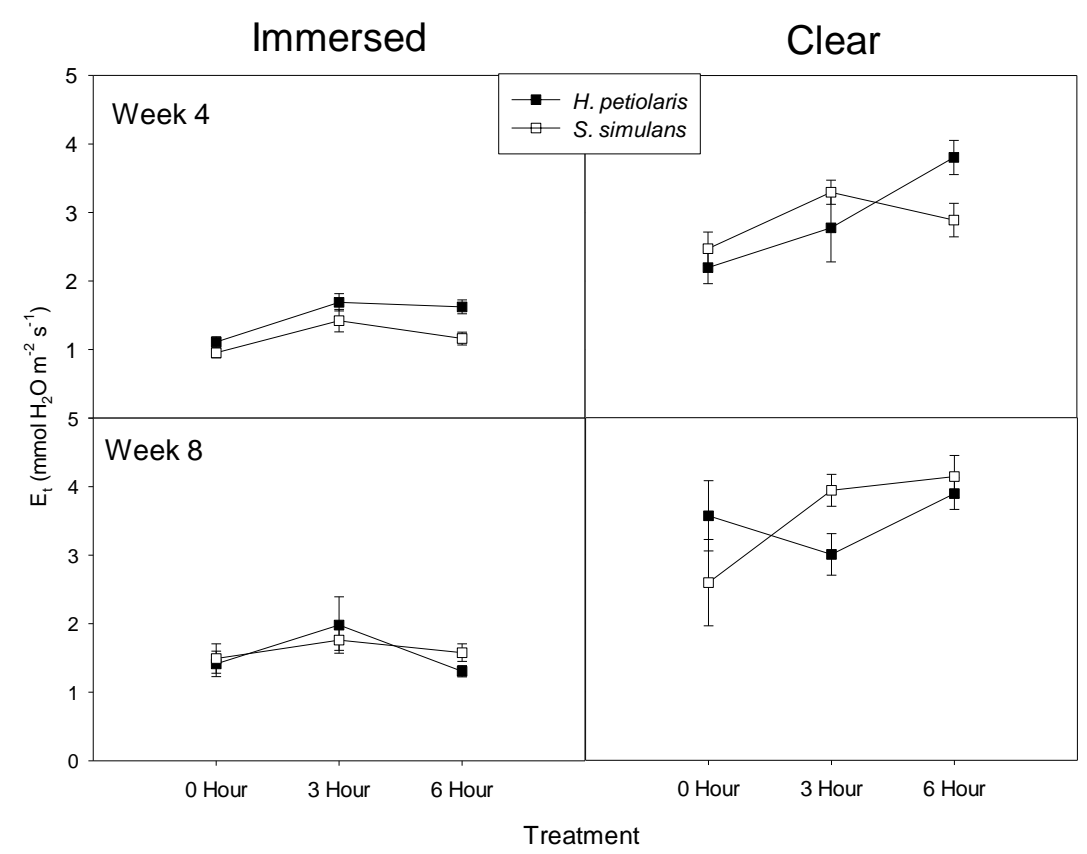

Figure 2. Mean \pm standard error evapotranspiration $\left(\mathrm{E}_{\mathrm{t}}\right)$ for Hydatica petiolaris and Solidago simulans by treatment, chamber condition, and week. 


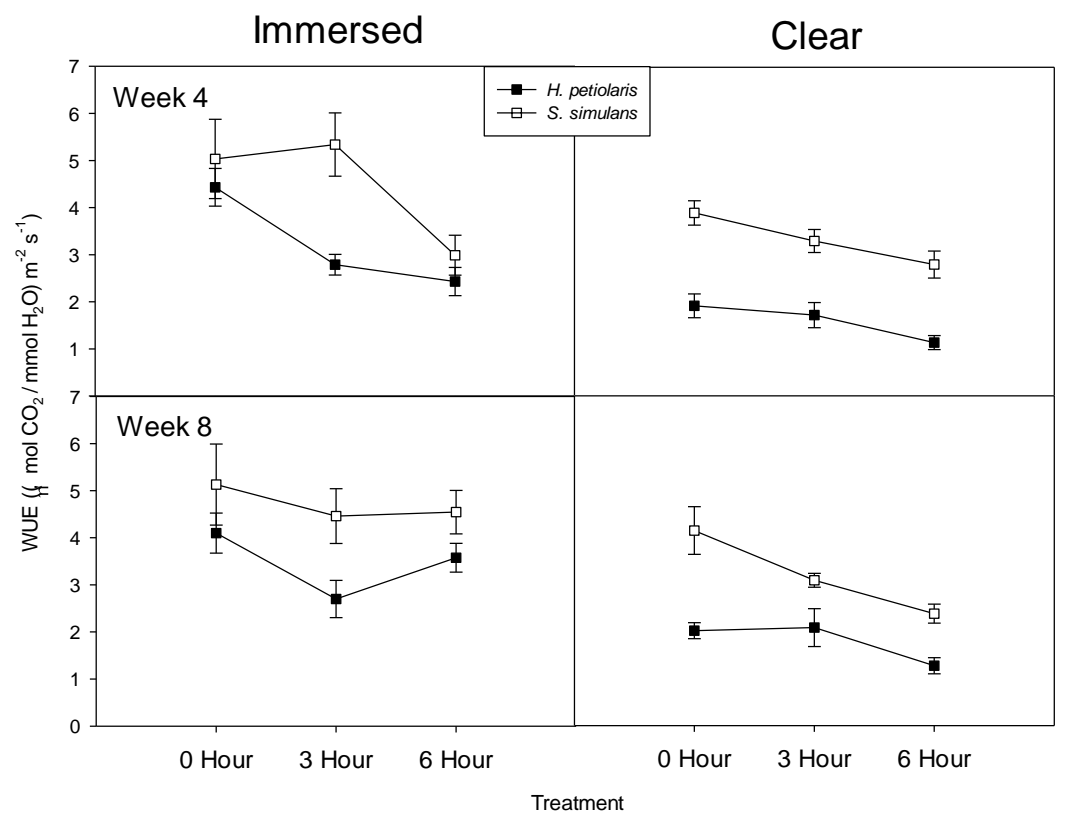

Figure 3. Mean \pm standard error water use efficiency (WUE) for Hydatica petiolaris and Solidago simulans by treatment, chamber condition, and week.

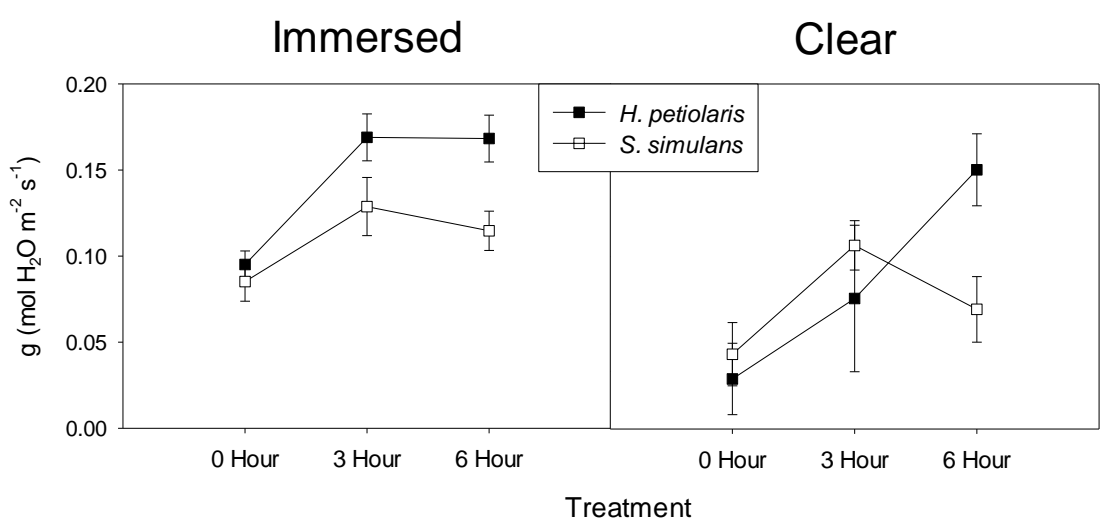

Figure 4. Mean \pm standard error stomatal conductance $\left(\mathrm{g}_{\mathrm{s}}\right)$ for Hydatica petiolaris and Solidago simulans by treatment, chamber condition, and week.

\subsection{Growth Parameters}

Relative growth rate decreased over time, with statistically significant differences between species and among treatments over time (Table 5; Figure 5). Relative growth rate declined steadily in the 6-hour treatment, while in the 3-hour treatment it increased to week four, then declined, and in the 0-hour treatment it increased in week two before declining until another increase at week six. Relative growth rate of $H$. petiolaris exceeded that of $S$. simulans for the first four weeks of treatment, but all species and treatment groups had equivalent low RGR (approximately 0.02) by the end of treatment. For all harvest parameters, mean values for $S$. simulans exceeded those for $\mathrm{H}$. petolaris (Table 6; Table 7). Treatment had a significant effect on root mass ( 3 hour $>0$ hour $=6$ hour), root to shoot ratio $(3$ hour $=6$ hour $>$ control $)$ and specific leaf mass $(3$ hour $>6$ hour $=0$ hour $)$ (Table 7$)$. 
Table 5. Results of repeated measures ANOVA of relative growth rate data. Significant results are shown in bold.

\begin{tabular}{lll}
\hline Factor & F Value & Pr $>$ F \\
\hline Time & $\mathbf{1 2 5 . 6 7}$ & $<\mathbf{0 . 0 0 0 1}$ \\
Time * Species & $\mathbf{5 . 1 3}$ & $\mathbf{0 . 0 0 0 3}$ \\
Time ${ }^{*}$ Treatment & $\mathbf{4 . 1 3}$ & $<\mathbf{0 . 0 0 0 1}$ \\
Time ${ }^{*}$ Species $*$ Treatment & 1.15 & 0.3265 \\
\hline
\end{tabular}

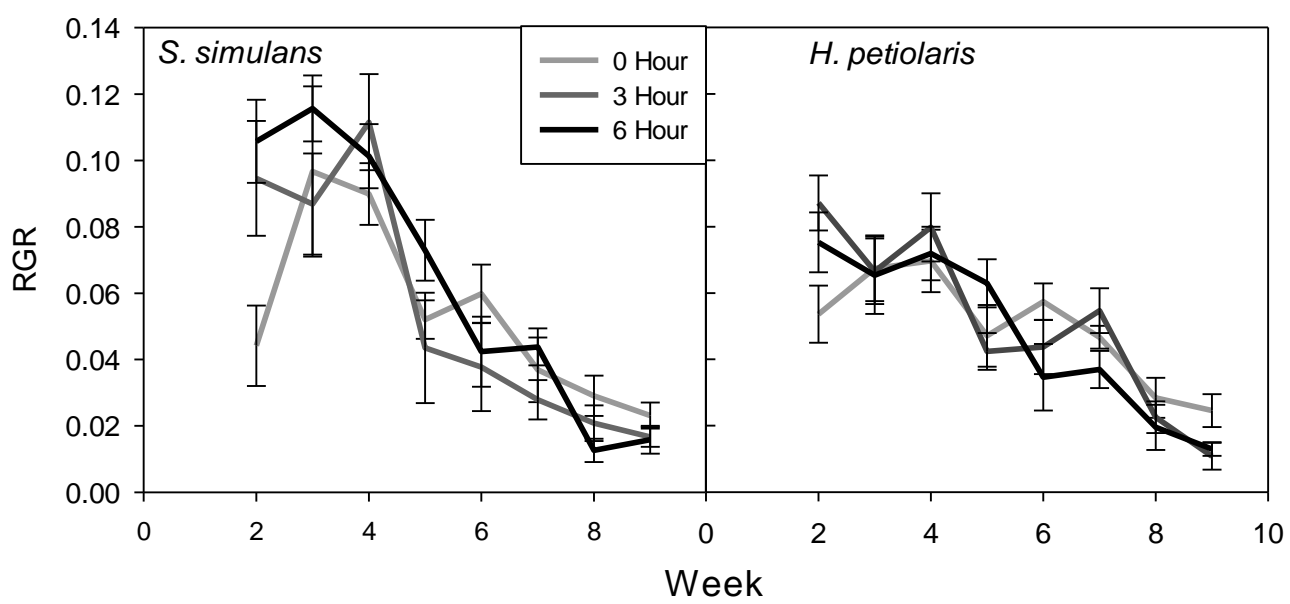

Figure 5. Relative growth rate over the duration of the experiment for Solidago simulans and Hydatica petiolaris by treatment.

Table 6 . Mean \pm standard error for harvest parameters by treatment and species.

\begin{tabular}{lllllll}
\hline Treatment/Species & $\begin{array}{l}\text { Leaf Mass } \\
(\mathbf{g})\end{array}$ & $\begin{array}{l}\text { Root Mass } \\
(\mathbf{g})\end{array}$ & $\begin{array}{l}\text { Stem Mass } \\
(\mathbf{g})\end{array}$ & $\begin{array}{l}\text { Root: } \\
\text { Shoot } \\
\text { Ratio }\end{array}$ & $\begin{array}{l}\text { Leaf Area } \\
\left(\mathbf{c m}^{2}\right)\end{array}$ & $\begin{array}{l}\text { Specific } \\
\text { Leaf Mass } \\
\left(\mathbf{m g ~ c m}^{-2}\right)\end{array}$ \\
\hline 0-hour H. petiolaris & $0.2098 \pm$ & $0.0584 \pm$ & $0.1948 \pm$ & $0.1633 \pm$ & $57.43 \pm$ & $3.639 \pm$ \\
& 0.0244 & 0.0061 & 0.0384 & 0.0163 & 6.42 & 0.143 \\
0-hour S. simulans & $0.9749 \pm$ & $0.3861 \pm$ & $0.4637 \pm$ & $0.2662 \pm$ & $195.10 \pm$ & $5.047 \pm$ \\
& 0.0581 & 0.0373 & 0.0332 & 0.0189 & 13.09 & 0.155 \\
3-hour H. petiolaris & $0.2841 \pm$ & $0.1006 \pm$ & $0.3163 \pm$ & $0.1970 \pm$ & $77.91 \pm$ & $3.682 \pm$ \\
& 0.0601 & 0.0146 & 0.0758 & 0.0323 & 16.76 & 0.141 \\
3-hour S. simulans & $1.2040 \pm$ & $0.7320 \pm$ & $0.5565 \pm$ & $0.3915 \pm$ & $207.50 \pm$ & $5.584 \pm$ \\
& 0.1869 & 0.1620 & 0.0804 & 0.0431 & 24.07 & 0.236 \\
6-hour H. petiolaris & $0.2704 \pm$ & $0.0820 \pm$ & $0.2721 \pm$ & $0.1478 \pm$ & $89.15 \pm$ & $3.004 \pm$ \\
& 0.0311 & 0.0188 & 0.0680 & 0.0110 & 8.86 & 0.088 \\
6-hour S. simulans & $0.8361 \pm$ & $0.4655 \pm$ & $0.3656 \pm$ & $0.3645 \pm$ & $168.23 \pm$ & $4.818 \pm$ \\
& 0.1420 & 0.0891 & 0.0559 & 0.0378 & 25.28 & 0.270 \\
\hline
\end{tabular}


Table 7. Results of ANOVA for harvest data. Significant results are shown in bold. Species * Treatment interaction was not significant for any parameter.

\begin{tabular}{lllll}
\hline Parameter & Factor & DF & F value & Pr $>$ F \\
\hline Leaf mass & Treatment & 2 & 2.66 & 0.0803 \\
& Species & $\mathbf{1}$ & $\mathbf{5 9 . 6 9}$ & $<\mathbf{0 . 0 0 0 1}$ \\
Root mass & Treatment & $\mathbf{2}$ & $\mathbf{2 . 6 6}$ & $\mathbf{0 . 0 2 7 6}$ \\
& Species & $\mathbf{1}$ & $\mathbf{3 5 . 6 9}$ & $<\mathbf{0 . 0 0 0 1}$ \\
Stem mass & Treatment & 2 & 2.62 & 0.0834 \\
& Species & $\mathbf{1}$ & $\mathbf{1 4 . 3 1}$ & $\mathbf{0 . 0 0 0 4}$ \\
Root to shoot ratio & Treatment & $\mathbf{2}$ & $\mathbf{4 . 3 5}$ & $\mathbf{0 . 0 1 8 3}$ \\
& Species & $\mathbf{1}$ & $\mathbf{4 3 . 2 5}$ & $<\mathbf{0 . 0 0 0 1}$ \\
Leaf area & Treatment & 2 & 1.01 & 0.3732 \\
& Species & $\mathbf{1}$ & $\mathbf{5 4 . 0 3}$ & $<\mathbf{0 . 0 0 0 1}$ \\
Specific leaf mass & Treatment & $\mathbf{2}$ & $\mathbf{8 . 3 9}$ & $\mathbf{0 . 0 0 0 7}$ \\
& Species & $\mathbf{1}$ & $\mathbf{1 0 3 . 5 4}$ & $<\mathbf{0 . 0 0 0 1}$ \\
\hline
\end{tabular}

\section{Discussion}

Light saturation point followed the hypothesized trend, with Lsat increasing with decreasing immersion duration. This pattern demonstrates the plastic ability of these plants to acclimate to a high-light environment by reaching maximal photosynthetic rates at higher PPFD. The microcosm light levels were much lower than plants would experience on an exposed rock outcrop (approximately $100 \mu \mathrm{mol} \mathrm{m}^{-2} \mathrm{~s}^{-1}$ in the microcosm versus 1000 or more $\mu \mathrm{mol} \mathrm{m} \mathrm{m}^{-1}$ at full sunlight). In future experiments, it would be beneficial to test the light response of plants under a broader range of light. Low light levels might explain why LCP did not increase with immersion duration as expected. For H. petiolaris, the lowest mean LCP occurred in the most immersed treatment, the mean LCP for the 3 -hour group exceeded that of the 0-hour group. The opposite trend was seen in $S$. simulans, with the lowest LCP in the 3-hour group, followed by the 0-hour, then the 6-hour groups. One explanation for these results is that the maximum LCP calculated was $27 \mu \mathrm{mol} \mathrm{m} \mathrm{s}^{-2}$ (6-hour $S$. simulans), and light levels consistently exceeded this PPFD during treatment, so there was no pressure for acclimation of LCP. It is possible that LCP would respond in plants grown in even lower light conditions than in this study, but this is extremely unlikely to occur in the plants' natural habitat.

The variation of physiological parameters according to chamber setting confirms that plants respond differently to clear and immersed conditions, driven by differences in VPD and light availability. Chamber rH during simulated immersion was lower than $\mathrm{rH}$ observed in the field, resulting in higher VPD during measurements as compared to field conditions (1.878 in chamber versus $0.517 \mathrm{kPa}$ in field conditions ${ }^{7}$ ). Higher VPD likely resulted in higher $\mathrm{E}_{\mathrm{t}}$ values for this study than would be observed under field conditions. Despite this difference, simulated immersed conditions resulted in decreased VPD and $\mathrm{E}_{\mathrm{t}}$ compared to simulated clear conditions for both four and eight week measurements. Increased VPD in the 'clear' chamber setting explains the increase of $E_{t}$ and the decrease of WUE in response to the greater water vapor concentration gradient. Chamber setting did not cause a significant difference is $\mathrm{g}_{\mathrm{s}}$ for either week. This indicates that differences in $\mathrm{P}_{\mathrm{n}}$ were driven by light and differences in $\mathrm{E}_{\mathrm{t}}$ were driven by VPD, rather than either factor being influenced by stomatal openness. Neither $P_{n}$ nor $E_{t}$ varied by treatment during 'immersed' conditions. The chamber PPFD of $200 \mu \mathrm{mol} \mathrm{m}^{-2} \mathrm{~s}^{-1}$ during these measurements was below the mean Lsat for S. simulans and only slightly higher than the mean Lsat for $\mathrm{H}$. petiolaris, so light was the likely limiting factor to photosynthetic rate during 'immersed' survey measurements. Light limitation across treatments led to comparable $\mathrm{P}_{\mathrm{n}}$ and low VPD kept $\mathrm{E}_{\mathrm{t}}$ near minimum values regardless of treatment, explaining why no significant pattern by treatment was observed.

For week four, low $\mathrm{g}_{\mathrm{s}}$ in the control treatment for both immersed and clear conditions contributed to lower $\mathrm{E}_{\mathrm{t}}$ and greater WUE. Decreased $\mathrm{g}_{\mathrm{s}}$ did not correlate with decreased $\mathrm{P}_{\mathrm{n}}$, indicating that the stomata closed enough to alter the diffusion rate of water vapor out of the leaf, but not enough to alter diffusion of $\mathrm{CO}_{2}$ into the leaf, because the two molecules have separate diffusional gradients ${ }^{17}$. This is supported by the lack of variation of stomatal limitation of photosynthesis by setting, treatment, or species, indicating that $\mathrm{CO}_{2}$ diffusion was not affected by stomatal behavior. Vapor pressure deficit likely acted as the strongest influence on physiological characteristics in the 
absence of stomatal limitation by controlling the rate of water diffusion out of the leaf, altering $\mathrm{E}_{\mathrm{t}}$ and WUE. For week eight, neither $\mathrm{g}_{\mathrm{s}}$ nor $\mathrm{E}_{\mathrm{t}}$ varied by treatment, but WUE was still greatest in the control treatment, possibly indicating acclimation. Knapp and Smith found that $g_{s}$ varied over the course of a growing season, becoming more sensitive to environmental factors as plant water stress increased ${ }^{18}$. Decreased water stress due to acclimation or root growth could explain why $\mathrm{g}_{\mathrm{s}}$ and $\mathrm{E}_{\mathrm{t}}$ differed by treatment during week four but not week eight. Acclimation to microcosm conditions could also explain why eight-week survey measurements yielded fewer and less significantly different results among treatment than four-week measurements. As predicted, the 0-hour immersion treatment resulted in the lowest $E_{t}$ values for week four. However, $E_{t}$ did not vary by treatment for week eight. The hypothesis that WUE would be greatest in the 0-hour treatment was confirmed. These results indicate that plants receiving less cloud immersion conserve more water, enabled by more responsive stomata in reaction to limited moisture availability. This is similar to the pattern seen by Knapp and Smith, in which plants with more restricted access to water had more sensitive stomatal response to environmental conditions, leading to lower $\mathrm{E}_{\mathrm{t}}$ and higher WUE as compared to counterparts that did not need to conserve water ${ }^{18}$. The response to $P_{n}$ to treatment did not support the hypothesis that plants in less immersed conditions would have higher maximum $P_{n}$ due to greater light availability, and therefore greater $\mathrm{P}_{\mathrm{n}}$ at a given light level as compared to plants exposed to more immersion. Because light level was low across treatments, it is probable that light did not vary enough among treatments to elicit acclimation of $\mathrm{P}_{\mathrm{n}}$.

The two species responded differently to treatment in terms of $\mathrm{P}_{\mathrm{n}}, \mathrm{g}_{\mathrm{s}}$, and $\mathrm{E}_{\mathrm{t}}$. The high values of the parameters for S. simulans in the 3-hour immersion treatment were unexpected based on the hypothesis that reduced immersion would lead to decreased $\mathrm{g}_{\mathrm{s}}$ and $\mathrm{E}_{\mathrm{t}}$. Hydatica petiolaris followed the expected trend for these parameters, but did not vary as strongly among treatments as $S$. simulans. Though the species responded differently to treatment for some parameters, both species followed the predicted trend of increased WUE with less frequent immersion in an attempt to conserve water. These results are a preliminary indicator that different rock outcrop species might vary in their response to decreased immersion, but the need to conserve water will be common. The two species also differed from each other regardless of treatment for $\mathrm{P}_{\mathrm{n}}, \mathrm{g}_{\mathrm{s}}, \mathrm{C}_{\mathrm{i}}$, and WUE. These differences can be attributed to the fact that they belong to different families and have species-based differences in morphology and physiology. The two species also differed for all growth parameters measured, demonstrating their morphological differences.

High root mass, root to shoot ratio, and specific leaf mass in the 3-hour treatment did not support the hypothesis that these parameters would be increased by water stress in the less immersed conditions. The hypothesis viewed these parameters as indicators of water stress, but this result suggests that they might also be influenced by other factors. The high SLM observed in the 3-hour treatment has been associated with more allocation of biomass to structural than metabolic functions and greater internal shading due to chloroplast stacking ${ }^{24}$. It is unclear why these parameters were highest in the 3-hour treatment, rather than following a gradient from longest to shortest immersion duration. It is likely that this study did not expose plants to severe enough water stress for a long enough period to elicit the expected response of greater specific leaf mass and carbon allocation to roots. In the future, designing a treatment to replicate water availability found in rock outcrop habitat and monitoring soil moisture in the microcosms would improve experiments of this type.

The variation of physiological parameters according to treatment is a sign of phenotypic plasticity in these species, and indicates potential to respond to changes in environmental conditions. Analysis of genetic variation in these species would provide more information about their genetic diversity and the possibility of selection pressure favoring plastic individuals in response to changing climate patterns ${ }^{13}$. Previous studies on the potential effects of climate change on plant populations ${ }^{5,6,14}$ have focused on tree species, which have the disadvantage of long generation time in adapting to rapid changes in temperature and moisture patterns. Long-lived species are more likely to respond to changing patterns through individual acclimation, while the short generation time of herbaceous perennials such as the species studied here is more conducive to adaptation to changing conditions through natural selection. Differences between the two study species, especially in terms of tissue mass, photosynthetic rate, water use efficiency, and light curve parameters, reflect some of the diversity among rock outcrop plants. For both species, predicted decrease in cloud immersion is likely to increase water stress and cause plants to acclimate through higher water use efficiency. The high tissue mass and photosynthetic rate of S. simulans plants in the 3hour treatment indicate that reduced immersion resulted in the most favorable conditions for growth. Hydatica petiolaris showed less plasticity according to treatment, but did have decreased $\mathrm{E}_{\mathrm{t}}$ and WUE in the 0-hour immersion treatment, indicating water-conserving acclimation. Solidago simulans is the less widespread of the two species, so it is surprising that it showed more phenotypic plasticity than $H$. petiolaris, which occurs in a wider variety of habitats. Applying the results of this study to rock outcrop plant populations indicates that at least some species have the potential to acclimate to changing weather patterns through plastic physiological responses to reduced cloud immersion. Specifically, plants will acclimate to decreased water availability by increasing water use 
efficiency. The differences in response between these species indicate that it is invalid to assume that all outcrop plants have the same optimal habitat requirements or will respond to changing climate conditions in the same ways.

\section{Acknowledgements}

Thanks to Dr. Beverly Collins for providing S. simulans seeds, Prof. Landon Ward for assistance with experimental design, Gwendolyn Casebeer, Kristin Emery, Karissa Keen, and Andrew Watson for assistance with data collection, and Dr. David Clarke, Dr. Jennifer Rhode Ward and the UNCA Botany Research Group for guidance in experimental design and comments on the manuscript. Funding was provided by the Undergraduate Research Program at the University of North Carolina at Asheville and the Izard Memorial Scholarship through Jay Kraynik and the Botanical Gardens at Asheville. LI-COR Li-6400s were purchased through National Science Foundation funds DBI-0420295 and DUE-942776. Growth Chambers were purchased through National Science FoundationDivision of Biological Infrastructure grant \#0821062.

\section{References}

1. Wiser SK. 1994. High-elevation cliffs and outcrops of the Southern Appalachians: vascular plants and biogeography. Castanea. 59(2): 85-116.

2. Wiser SK, Peet RK, White PS. 1996. High-elevation rock outcrop vegetation of the Southern Appalachian Mountains. Journal of Vegetation Science. 7(5): 703-722.

3. Godt JW, Johnson BR, Hamrick JL. 1996. Genetic diversity and population size in four rare Southern Appalachian plant species. Conservation Biology. 10(3): 796-805.

4. Reinhardt K, Smith WK. 2008. Impacts of cloud immersion on microclimate, photosynthesis and water relations of Abies fraseri (Pursh.) Poiret in a temperate mountain cloud forest. Oecologia. 158(2): 229-238.

5. Berry ZC, Smith WK. 2012. Cloud pattern and water relations in Picea rubens and Abies fraseri, southern Appalachian Mountains, USA. Agricultural and Forest Meteorology. 162-163: 27-34.

6. Berry ZC, Smith WK 2013. Ecophysiological importance of cloud immersion in a relic spruce-fir forest at elevational limits, southern Appalachian Mountains, USA. Oecologia. doi: 10.1007/s00442-013-2653-4

7. Culatta KE, Horton JL. Unpublished data.

8. Chernykh IV, Alduchov OA, Eskridge RE. 2001. Trends in low and high cloud boundaries and errors in height determination of cloud boundaries. Bulletin of the American Meteorological Society. 82: 1941-1947.

9. Foster P. 2001. The potential negative impacts of global climate change on tropical montane cloud forests. Earth-Science Reviews. 5: 73-106.

10. Richardson AD, Denny EG, Siccama TG, Lee X. 2003. Evidence for a rising cloud ceiling in Eastern North America. Journal of Climate. 16:2093-2098.

11. Walther G, Post E, Convey P, Menzel A, Parmesan C, Beebee TJC, Fromentin J, Hoegh-Guldberg ), Bairlein F. 2002. Ecological responses to recent climate change. Nature. 416: 389-395.

12. Bartomeus I, Ascher JS, Wagner D, Danforth BN, Colla S, Kornbluth S, Winfree

R. 2011. Climate-associated phonological advances in bee pollinators and bee-pollinated plants. Proceedings of the National Academy of Sciences. 108(51): 20645-20649.

13. Jump AS, Penuelas J. 2005. Running to stand still: adaptation and the response of plants to rapid climate change. Ecology Letters. 8: 1010-1020.

14. Potter K, Hargrove W, Koch F. 2010. Predicting climate change extirpation risk for central and southern Appalachian forest tree species. Proceedings from the conference on the ecology and management of high-elevation forests in the central and southern Appalachian Mountains. 2009 May 14-15; Slatyfork WV.

15. Reinhardt K, Smith WK, Carter GA. 2010. Clouds and cloud immersion alter photosynthetic light quality in a temperate mountain cloud forest. Botany. 88: 462-470.

16. Johnson DM, Smith WK. 2008. Cloud immersion alters microclimate, photosynthesis and water relations in Rhododendron catawbiense and Abies fraseri seedlings in the southern Appalachian Mountains, USA. Tree Physiology. 28: 385-392.

17. Jones HG. 1998. Stomatal control of photosynthesis and transpiration. Journal of Experimental Botany. 49: 387-398. 
18. Knapp AK, Smith WK. 1988. Effect of water stress on stomatal and photosynthetic responses in subalpine plants to cloud patterns. American Journal of Botany. 75(6): 851-858.

19. Weakley, AS. 2012. Flora of the Southern and Mid-Atlantic states: working draft of 30 November 2012. Chapel Hill: University of North Carolina Herbarium.

20. Creelman RA, Mason HS, Bensen RJ, Boyer JS, Mullet JE. 1990. Water deficit and abscisic acid cause differential inhibition of shoot verses root growth in soybean seedlings. Plant Physiology. 92: 205-214.

21. Poorter H, Niinemets U, Poorter L, Wright IJ, Villar R. 2009. Causes and consequences of variation in leaf mass per area (LMA): a meta-analysis. New Phytologist. 182:565-588.

22. Farquhar GD, Sharkey TD. 1982. Stomatal conductance and photosynthesis. Annual Review of Plant Physiology. 33(1): 317-345.

23. SAS Institute Inc. 2002 - 2008. Version 9.2 Statistical Analysis System, Cary, NC, USA.

24. Reich PB, Ellsworth DS, Walters MB. 1998. Leaf structure (specific leaf area) modulates photosynthesisnitrogen relations: evidence from within and across species and functional groups. Functional Ecology. 12: 948-958. 